\title{
POLA DISTRIBUSI DAN TEKNOLOGI PENGELOLAAN HASIL TANGKAPAN PELABUHAN PERIKANAN DI WILAYAH PANTURA JAWA
}

\section{DISTRIBUTION PATTERNS AND TECHNOLOGY OF CATCH FISHING PORTS MANAGEMENT IN THE JAVA PANTURA}

\author{
Andi Perdana Gumilang ${ }^{1}$, Iin Solihin ${ }^{2}$, Sugeng Hari Wisudo ${ }^{2}$ \\ ${ }^{1}$ Program Studi Teknologi Perikanan Laut, Sekolah Pascasarjana \\ ${ }^{2}$ Departemen Pemanfaatan Sumberdaya Perikanan, \\ Fakultas Perikanan dan Ilmu Kelautan, Institut Pertanian Bogor \\ Korespondensi : andi.sangpenakluk@gmail.com, iinsolikhin.psp46@gmail.com
}

\begin{abstract}
Distribution of catch fishing port is important because if the catch is distributed, the product sales will catch up to the location of the consumer. This study aimed to obtain the distribution pattern of the catch at the fishing port in the north coast of Java. Conducted a comparative descriptive analysis based on the market, connectivity and marketing offender through the presentation of maps, charts and tables. The results showed that the distribution pattern of the catch on the north coast of Java based market include market distribution locally, regionally, outside Java and export. Distribution of catches in the fishing port north coast of Java are distributed to local and regional markets. The supply of fish to the domestic market in the fishing port of the northern coast of Java has been adequately met as much as $91.32 \%$ and the remaining $8.68 \%$ for export. The pattern of distribution of catches by fishing port connectivity was found that the fishing port as a marketer is PPS Nizam Zachman Jakarta, while the fishing port as a supplier is PPS Nizam Zachman Jakarta and PPN Pekalongan. The distribution pattern of the catch of fishing ports based marketing perpetrator obtained 7.5 patterns based on the pattern of production of fish from the fishing port and 2 pattern based on the production of fish from outside the port. Perpetrators distribution of catches locally, regionally, and the Outer include fishermen, traders, wholesalers and retailers. While the distribution of exports were fishermen, wholesalers and agents the fishing industry to be sent to the country of destination.
\end{abstract}

Keyword: connectivity, the distribution of catches, the fishing port, the north coast of Java

ABSTRAK

Distribusi hasil tangkapan pelabuhan perikanan adalah penting karena hasil tangkapan perikanan adalah suatu bahan makanan yang sangat mudah menjadi rusak dan kemudian membusuk (Clusa dan Ward 1996), sehingga dibutuhkan upaya pendistribusian agar penjualan produk hasil tangkapan bisa sampai ke lokasi konsumen untuk dikonsumsi. Penelitian ini bertujuan untuk mendapatkan pola distribusi hasil tangkapan pada pelabuhan perikanan di wilayah pantura Jawa. Metode penelitian adalah metode survei terhadap pola distribusi hasil tangkapan. Analisis dilakukan secara deskriptif komparatif berdasarkan pasar, konektivitas dan pelaku pemasaran melalui penyajian peta, bagan dan tabel. Hasil penelitian menunjukkan bahwa pola distribusi hasil tangkapan di pantura Jawa berdasarkan pasar mencakup distribusi pasar lokal, regional, luar Jawa dan ekspor. Distribusi hasil tangkapan pada pelabuhan perikanan pantura Jawa sebagian besar didistribusikan untuk pasar lokal dan regional. Pasokan ikan untuk pasar domestik di pelabuhan perikanan Pantura Jawa sudah cukup terpenuhi sebanyak 91.32\% dan sisanya 8.68\% untuk ekspor. Pola distribusi hasil tangkapan berdasarkan konektivitas pelabuhan perikanan didapatkan bahwa pelabuhan perikanan sebagai pemasar adalah PPS Nizam Zachman Jakarta, sedangkan pelabuhan perikanan sebagai pemasok adalah PPS Nizam Zachman Jakarta dan PPN Pekalongan. Pola distribusi hasil tangkapan pelabuhan perikanan berdasarkan pelaku pemasaran didapatkan 7 pola yakni 5 pola berdasarkan produksi ikan dari dalam pelabuhan dan 2 pola berdasarkan produksi ikan dari luar pelabuhan. Pelaku pendistribusian hasil tangkapan secara lokal, regional, dan luar Jawa meliputi nelayan, pedagang pengumpul, pedagang grosir dan pedagang eceran. Sementara pendistribusian ekspor adalah nelayan, pedagang grosir, dan agen perusahaan industri perikanan untuk dikirim ke negara tujuan.

Kata kunci: distribusi hasil tangkapan, konektivitas, pelabuhan perikanan, pantura Jawa 


\section{PENDAHULUAN}

\section{Latar belakang}

Undang-undang RI No.45 tahun 2009 tentang perikanan menyatakan bahwa pelabuhan perikanan memiliki fungsi pemerintahan dan pengusahaan guna mendukung kegiatan yang berhubungan dengan pengelolaan dan pemanfaatan sumberdaya ikan dan lingkungannya mulai dari praproduksi, produksi, pengolahan sampai dengan distribusi pemasaran. Distribusi berperan penting dalam suatu pelabuhan perikanan karena jika hasil tangkapan tidak didistribusikan, penjualan produk hasil tangkapan tidak akan sampai hingga ke tangan konsumen.

Slamet (2013) menyebutkan distribusi mempunyai arti penting karena barangbarang dapat terjual luas sampai ke lokasi konsumen, sehingga konsumen akan mudah mendapatkan barang-barang yang dibutuhkan. Di sisi lain pengembangan fungsi pelabuhan dari pusat pelayanan menjadi pusat distribusi pemasaran akan membuat hasil pemanfaatan sumberdaya ikan oleh nelayan menjadi optimal. Peran pelabuhan perikanan sebagai mata rantai dalam proses transportasi mulai dari tempat asal barang sampai ke tujuan menjadi sangat strategis untuk dikembangkan (Muninggar 2008).

Pelabuhan perikanan merupakan pusat aktivitas ekonomi perikanan yang akan memberikan dampak terhadap pertumbuhan ekonomi wilayah secara keseluruhan. Aktivitas pelabuhan perikanan tersebut tidak terlepas dari proses saling mempengaruhi dengan pelabuhan perikanan lainnya. Hal ini disebabkan karena adanya kesamaan jenis, karakteristik dan pelaku aktivitas di pelabuhan perikanan tersebut (Solihin dan Putri 2012).

Salah satu wilayah yang menjadi sasaran dalam aktivitas penangkapan dan distribusi hasil tangkapan adalah Pantai Utara (Pantura) Jawa. Pelabuhan perikanan di wilayah Pantura Jawa merupakan sentra produksi penangkapan ikan yang berpotensi memainkan peranannya dalam distribusi hasil tangkapan mengingat wilayah Pantura Jawa merupakan daerah pasar yang potensial dan berkontribusi cukup besar terhadap volume produksi perikanan laut. Berdasarkan tempat pendaratan ikan, pada tahun 2013 diketahui bahwa wilayah pendaratan ikan di Pantura Jawa adalah tertinggi ke dua dari volume produksi perikanan laut nasional atau tertinggi di wilayah Indonesia bagian barat yaitu sebesar $15,68 \%$ atau 894.000 ton (KKP 2014). Sekitar $65 \%$ produksi hasil perikanan laut tersebut dihasilkan oleh nelayan-nelayan yang terdapat di pelabuhan sepanjang Pantura Jawa.
Namun demikian permasalahan yang masih dijumpai adalah belum sinerginya pelabuhan perikanan di wilayah Pantura Jawa dalam pendistribusian hasil tangkapan. Pelabuhan perikanan seakan-akan berdiri sendiri tanpa adanya interaksi dengan pelabuhan lain. Akibatnya pelabuhan perikanan belum mampu menjadi media koneksi untuk mendistribusikan hasil tangkapan ikan sehingga permasalahan kelebihan pasokan dan penurunan mutu hasil tangkapan terjadi. Hal ini disebabkan karena belum adanya sistem koneksi atau sistem interaksi antar pelabuhan perikanan dan pembagian peran antar pelabuhan perikanan tersebut baik sebagai pelabuhan pengumpan, pengumpul maupun hubungan regional (Solihin dan Putri 2012).

Salah satu cara yang dapat digunakan untuk mengoptimalisasi fungsi pelabuhan perikanan dalam hal distribusi pemasaran adalah dengan menggunakan informasi pola distribusi hasil tangkapan di kedua belas pelabuhan perikanan pantura Jawa karena bila dilihat dari segi aktivitasnya samasama melayani kebutuhan ikan untuk didistribusikan. Berdasarkan keadaan tersebut, maka penelitian mengenai distribusi hasil tangkapan pelabuhan perikanan menjadi perlu dilakukan. Penelitian ini bertujuan untuk mendapatkan pola distribusi hasil tangkapan pada pelabuhan perikanan di wilayah Pantura Jawa. Hasil yang diharapkan adalah dapat dijadikan sebagai sumber informasi mengenai pola distribusi hasil tangkapan di pelabuhan perikanan pantura Jawa kepada pihak pengelola serta instansi terkait untuk pengembangan dan perbaikan dalam pendistribusian hasil tangkapan.

\section{METODE PENELITIAN}

Penelitian dilaksanakan pada bulan April-Juni tahun 2015 dengan tempat penelitian di dua belas Pelabuhan Perikanan wilayah pantai utara Jawa meliputi PPN Karangantu Kota Serang Provinsi Banten, PPS Nizam Zachman Jakarta Kota Jakarta Utara Provinsi DKI Jakarta, PPN Kejawanan Kota Cirebon Provinsi Jawa Barat, PPP Eretan Wetan Kabupaten Indramayu Provinsi Jawa Barat, PPI Karangsong Kabupaten Indramayu Provinsi Jawa Barat, PPN Pekalongan Kota Pekalongan Provinsi Jawa Tengah, PPP Asemdoyong Kabupaten Pemalang Provinsi Jawa Tengah, PPP Klidang Lor Kabupaten Batang Provinsi Jawa Tengah, PPP Morodemak Kabupaten Demak Provinsi Jawa Tengah, PPP Bajomulyo Kabupaten Pati Provinsi Jawa Tengah, PPN Brondong Kabupaten Lamongan Provinsi Jawa Timur dan PPI Bulu Kabupaten Tuban Provinsi Jawa Timur, seperti yang ditunjukkan pada Gambar 1. 


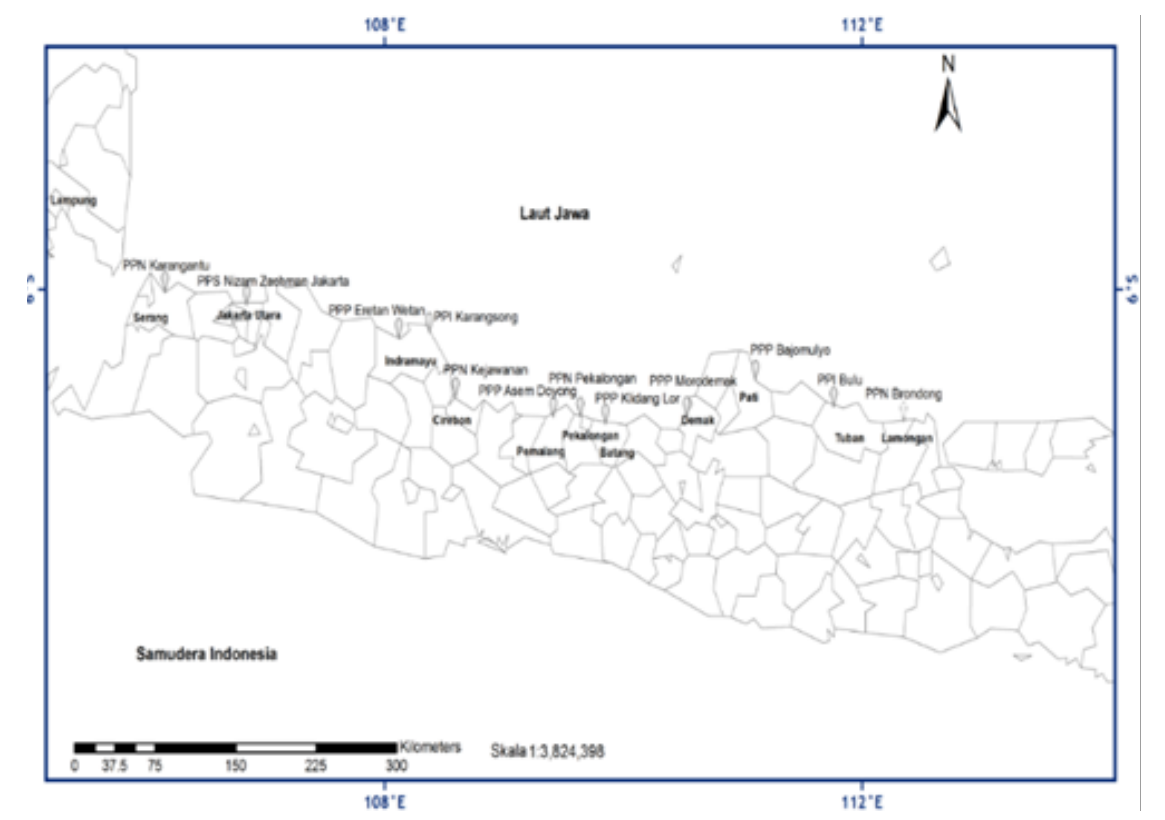

Gambar 1. Lokasi penelitian 12 pelabuhan perikanan di Pantai Utara Jawa

\section{Metode pengumpulan data}

Metode penelitian yang digunakan yaitu metode survei. Metode survei adalah penyelidikan yang diadakan untuk memperoleh fakta-fakta dari gejalagejala yang ada dan mencari keteranganketerangan secara faktual dari suatu kelompok (Nazir 2011). Survei dilakukan dengan mengamati dan mengkaji faktorfaktor yang berkaitan dengan distribusi hasil tangkapan di dua belas pelabuhan perikanan antara lain aktivitas distribusi, jalur-jalur pemasaran, volume distribusi pemasaran hasil tangkapan, dan tujuan distribusi pemasaran.

Data yang diambil meliputi data primer dan data sekunder. Data primer diperoleh melalui pengamatan terhadap berbagai aktivitas yang dilakukan di pelabuhan pantura Jawa antara lain PPN Karangantu, PPS Nizam Zachman Jakarta, PPN Kejawanan, PPP Eretan Wetan, PPI Karangsong, PPN Pekalongan, PPP Asemdoyong, PPP Klidang Lor, PPP Morodemak, PPP Bajomulyo, PPN Brondong dan PPI Bulu. Selain itu dilakukan wawancara terhadap para responden dengan metode purposive sampling yaitu mengambil sampel yang dianggap dapat mewakili kepentingan penelitian dan dapat berkomunikasi dengan baik. Responden yang diwawancarai pada masing-masing pelabuhan adalah pengelola pelabuhan perikanan bidang operasional berjumlah 2 orang, 10 nelayan, dan 4 bakul/pedagang ikan. Data sekunder diperoleh dari beberapa instansi terkait antara lain pihak Pelabuhan Perikanan, Pusat Informasi Pelabuhan Perikanan (PIPP) Kementerian Kelautan dan Perikanan, Badan Pusat Statistik dan studi literatur internet.

\section{Analisis data}

Analisis data yang digunakan dalam penelitian ini adalah analisis deskriptif komparatif terhadap pola distribusi hasil tangkapan berdasarkan pasar, konektivitas dan pelaku pemasaran. Data primer dan data sekunder yang telah dikumpulkan disajikan dalam bentuk peta, bagan dan tabel. Pemetaan dibuat dari analisis deskriptif menggunakan software pembuat peta agar lebih informatif. Adapun metode dalam pembuatan peta sebagai berikut :

1. Membuat konsep peta, merinci informasi yang akan ditampilkan di dalam peta. Informasi tersebut digunakan untuk merancang basis data;

2. Mengumpulkan data sesuai dengan rancangan pemetaan yang akan disusun;

3. Memasukkan data dalam database;

4. Mendigitasi peta;

5. Memetakan distribusi hasil tangkapan di kedua belas pelabuhan perikanan pantura Jawa berdasarkan daerah pasar dan konektivitas pelabuhan;

6. Menampilkan peta dalam bentuk tematik.

\section{HASIL DAN PEMBAHASAN}

\section{Distribusi hasil tangkapan berdasarkan pasar}

Pelabuhan perikanan sangat penting perannya terhadap perikanan laut, karena pelabuhan perikanan merupakan center perekonomian mulai saat ikan didaratkan pasca penangkapan dari fishing ground-nya sampai awal ikan dipasarkan di pelabuhan perikanan (Lubis 2011). Berdasarkan hasil pengamatan terhadap sistem pemasaran 
dan distribusi hasil tangkapan yang ada pada pelabuhan perikanan di wilayah pantura Jawa dapat dikelompokkan menjadi 4 tipe yaitu distribusi pasar lokal, regional, luar Jawa dan luar negeri. Tipe pemasaran luar negeri dilakukan melalui bandara dan pelabuhan laut. Distribusi pemasaran hasil perikanan ke luar negeri di pulau Jawa terdapat pada provinsi DKI Jakarta dan Jawa Timur. Hal ini dikarenakan provinsi tersebut memiliki pelabuhan besar yang aktif melakukan kegiatan ekspor ke luar negeri. Seperti provinsi DKI Jakarta memiliki pelabuhan Tanjung Priok, begitu juga dengan provinsi Jawa Timur memiliki pelabuhan Tanjung Perak.

Berdasarkan Tabel 1 aktivitas pelabuhan perikanan yang menjalankan distribusi secara keseluruhan baik lokal, regional, luar Jawa dan luar negeri (ekspor) adalah PPS Nizam Zachman Jakarta dan PPN Brondong. Distribusi hasil tangkapan pada pelabuhan perikanan Pantura Jawa sebagian besar didistribusikan untuk pasar lokal dan regional dengan PPS Nizam Zachman Jakarta sebagai pelabuhan yang mendistribusikan hasil tangkapan terbesar yaitu 39.779.871 kg (lokal) dan 151.570.441 kg (regional), sedangkan aktivitas pelabuhan perikanan yang mendistribusikan hasil tangkapannya ke pasar luar Jawa hanya terdapat pada PPS Nizam Zachman Jakarta, PPN Brondong, dan PPI Bulu. Sementara untuk pasar ekspor terdapat pada PPS Nizam Zachman Jakarta, PPN Kejawanan dan PPN Brondong. Jenis hasil tangkapan pelabuhan perikanan pantura Jawa umumnya didominasi oleh ikan pelagis kecil.

Hal ini disebabkan posisi pelabuhan perikanan yang berdekatan dengan daerah penangkapan (forelana) di perairan laut Jawa atau Wilayah Pengelolaan Perikanan (WPP) 712. Aktivitas distribusi terdiri dari distribusi ikan segar, ikan beku dan ikan olahan. Umumnya, pendistribusian hasil tangkapan dari pelabuhan perikanan pantura Jawa didominasi menggunakan jalur darat.

Berdasarkan pengamatan, frekuensi tujuan distribusi pemasaran terbesar terdapat pada daerah Bandung, DKI Jakarta dan Semarang. Adapun tiga daerah dengan penerimaan volume distribusi hasil tangkapan terbesar berada pada daerah Banten (27.28\%), Jakarta Utara (15.90\%) dan Surabaya (12.64\%). Besarnya volume di daerah tersebut disebabkan lokasi tersebut memiliki jumlah penduduk yang cukup tinggi sehingga permintaan konsumsi ikan menjadi cenderung meningkat. Disamping lokasinya yang strategis karena berdekatan dengan akses bandara internasional dan pelabuhan laut.

Distribusi hasil tangkapan pelabuhan perikanan di Pantura Jawa melibatkan proses pengembangan pelabuhan perikanan yang dipengaruhi oleh faktor kewilayahan. Salah satu faktor kewilayahan pelabuhan perikanan adalah penduduk suatu wilayah, terutama dalam konsumsi ikan yang juga dapat diartikan sebagai potensi pasar (PKSPL 2000). Data Kementerian Kelautan dan Perikanan menunjukkan bahwa tingkat konsumsi/kapita penduduk secara nasional pada tahun 2014 sebesar 38 kg/kapita/ tahun. Apabila volume distribusi pemasaran 12 pelabuhan perikanan pantura Jawa sebesar 274.012.994 kg/tahun untuk dipasarkan di dalam negeri sebanyak $91.32 \%$ atau $250.228 .467 \mathrm{~kg}$ dan sisanya $8.68 \%$ atau $23.784 .528 \mathrm{~kg}$ untuk diekspor, maka diperkirakan jumlah konsumen dalam negeri yang akan mengkonsumsi ikan dari 12 pelabuhan perikanan di pantura Jawa sebanyak 250.228.467 kg dibagi $38 \mathrm{~kg}$ menjadi 6.584 .960 orang. Dari volume distribusi pemasaran penduduk dalam negeri sebesar 250.228.467 kg, maka didistribusikan untuk pasar Jawa sebesar $85.76 \%$ atau 234.996.868,41 kg dan untuk pasar luar Jawa sebesar 5.56\% atau $15.231 .598,47 \mathrm{~kg}$ sebagaimana pada Tabel 2.

Berdasarkan Tabel 2 pasokan ikan untuk pasar domestik di pelabuhan perikanan pantura Jawa sudah cukup dipenuhi oleh hasil tangkapan nelayan setempat. Namun untuk ekspor, pasokan ikan hanya mampu memenuhi $8.68 \%$. Permasalahan ketersediaan pasokan ikan menjadi hal utama khususnya bagi pihak yang memasarkan produk perikanan tujuan ekspor. Untuk itu penerapan konektivitas / jejaring antar pelabuhan perikanan guna menjamin ketersediaan pasokan ikan dengan pengembangan integrasi sistem informasi antar pelabuhan perikanan terkait dengan pemasaran baik lokal maupun ekspor menjadi penting. Dalam kerangka sistem logistik ikan nasional perhatian terhadap sistem logistik bidang perikanan harus ditingkatkan, karena peningkatan produksi perikanan akan mempunyai pengaruh yang besar dalam meningkatkan perekonomian masyarakat jika diikuti dengan sistem logistik yang baik (Mai et al. 2010). Lebih lanjut potensi perikanan yang besar jika dikelola dengan baik dapat dijadikan penopang ketahanan pangan yang efektif (Srinivasan 2010). 
Tabel 1. Volume distribusi pemasaran ikan di 12 pelabuhan perikanan Pantura Jawa

\begin{tabular}{lllll}
\hline Pelabuhan Perikanan & \multicolumn{1}{c}{ Lokal } & \multicolumn{1}{c}{ Regional } & Luar jawa & Luar negeri \\
\hline PPN Karangantu & 15.680 & 1.222 & 0 & 0 \\
PPS Nizam Zachman & 39.779 .871 & 151.570 .441 & 11.869 .962 & 16.268 .642 \\
PPN Kejawanan & 13.262 & 0 & 0 & 865.576 \\
PPP Eretan Wetan & 66.190 & 46.190 & 0 & 0 \\
PPI Karangsong & 1.018 & 1.885 & 0 & 0 \\
PPN Pekalongan & 12.923 & 4.293 .444 & 0 & 0 \\
PPP Asemdoyong & 2.325 & 5.375 & 0 & 0 \\
PPP Klidang Lor & 1.702 & 7.000 & 0 & 0 \\
PPP Morodemak & 26.644 & 17.568 & 0 & 0 \\
PPP Bajomulyo & 29.071 & 26.462 & 0 & 0 \\
PPN Brondong & 30.149 .731 & 8.881 .759 & 3.357 .281 & 6.650 .310 \\
PPI Bulu & 20.791 & 26.313 & 4.355 & 0 \\
\hline Jumlah & 70.119 .208 & 164.877 .661 & 15.231 .598 & 23.784 .528 \\
\hline
\end{tabular}

Tabel 2. Distribusi pemasaran ikan 12 pelabuhan di wilayah Pantura Jawa

\begin{tabular}{lrl}
\hline Pelabuhan Perikanan & \multicolumn{1}{c}{ Lokal } & Regional \\
\hline Pasar Jawa & $234.996 .868,41$ & 85,76 \\
Pasar Luar Jawa & $152.315 .98,47$ & 5,56 \\
Pasar Ekspor & 23.784 .528 & 8,68 \\
\hline Jumlah & $274.012 .994,89$ & 100 \\
\hline
\end{tabular}

\section{Distribusi hasil tangkapan berdasarkan konektivitas}

Sebagaimana terdapat pada Gambar 2 terlihat bahwa antara PPN Karangantu, PPS Nizam Zachman, PPN Pekalongan dan PPN Brondong terdapat koneksi, begitu juga PPP Morodemak dan PPP Bajomulyo. PPS Nizam Zachman menyalurkan produksi ikannya ke PPN Karangantu, PPN Pekalongan, dan PPN Brondong. Sebaliknya, PPN Karangantu, PPN Pekalongan dan PPN Brondong menyalurkan kelebihan produksi ikannya ke PPS Nizam Zachman, begitu juga dengan PPN Pekalongan dan PPN Brondong serta PPP Morodemak dan PPP Bajomulyo walaupun secara tidak langsung. Hal tersebut karena ikan disalurkan terlebih dahulu ke pelabuhan perikanan lainnya di sekitar wilayah pantura Jawa untuk selanjutnya disalurkan ke pelabuhan yang dituju.

Pelabuhan perikanan di Pantura
Jawa yang memiliki konektivitas ke luar Jawa hingga luar negeri dengan volume distribusi ikan terbesar adalah PPS Nizam Zachman Jakarta. Hal itu diindikasikan dari kemampuannya yang menyalurkan volume distribusi pemasaran ikan sebesar $77.93 \%$ untuk luar Jawa dan $68.40 \%$ untuk luar negeri. Pelabuhan tersebut memiliki konektivitas dengan pelabuhan perikanan lainnya di luar Jawa seperti pelabuhan perikanan di Lampung, Sumut, Kepulauan Bangka Belitung dan Bali sedangkan konektivitas dengan beberapa pelabuhan perikanan di luar negeri seperti pelabuhan di negara tetangga (Malaysia, Singapura, Thailand, Filipina), Taiwan, Tiongkok, Jepang dan beberapa pelabuhan perikanan di benua Amerika dan Eropa.

Konektivitas di PPS Nizam Zachman Jakarta yang terjalin dengan pelabuhan perikanan di pulau Jawa, luar Jawa bahkan ke luar negeri menjadikan PPS Nizam Zachman sebagai pusat pemasaran 
pelabuhan perikanan di pantura Jawa. Selain pelabuhan perikanan pemasar PPS Nizam Zachman Jakarta juga sebagai pelabuhan perikanan pemasok sebagaimana pada Tabel 3.

Tabel 3 menunjukkan bahwa pelabuhan perikanandiPanturaJawasebagai pelabuhan perikanan pemasar adalah PPS Nizam Zachman karena memiliki nilai lebih besar dibanding pelabuhan lainnya. Hal ini dikarenakan pelabuhan tersebut memiliki volume distribusi pemasaran hasil tangkapan terbesar dibanding dengan pelabuhan lainnya, sedangkan pelabuhan perikanan sebagai pemasok di pantura Jawa adalah PPS Nizam Zachman dan PPN Pekalongan karena pelabuhan tersebut memasok penyediaan bahan baku ikan ke pelabuhan perikanan lainnya paling banyak di wilayah pantura Jawa.

Dalam hal pemasaran, Charles (2001) mengatakan bahwa interaksi pemasaran ikan dan pengembangan ekonomi dapat dilihat dari tiga dampak yaitu (i) dampak pemasaran (peningkatan permintaan konsumen, perbaikan sistem distribusi, perbaikan akses pasar, peningkatan alternatif pekerjaan dan peningkatan pemberdayaan nelayan), (ii) dampak menengah (peningkatan produksi pada ikan yang belum dimanfaatkan, saluran pemasaran yang lebih baik, peningkatan ekspor/pertukaran luar negeri, pengurangan ketergantungan nelayan dan pedagang perantara berkurang yang menyebabkan peningkatan pendapatan nelayan), dan (iii) dampak pengembangan (kesempatan kerja yang lebih dan ketersediaan makanan, ketersediaan protein yang lebih, perbaikan keseimbangan pasar, dan pembangunan masyarakat perikanan).

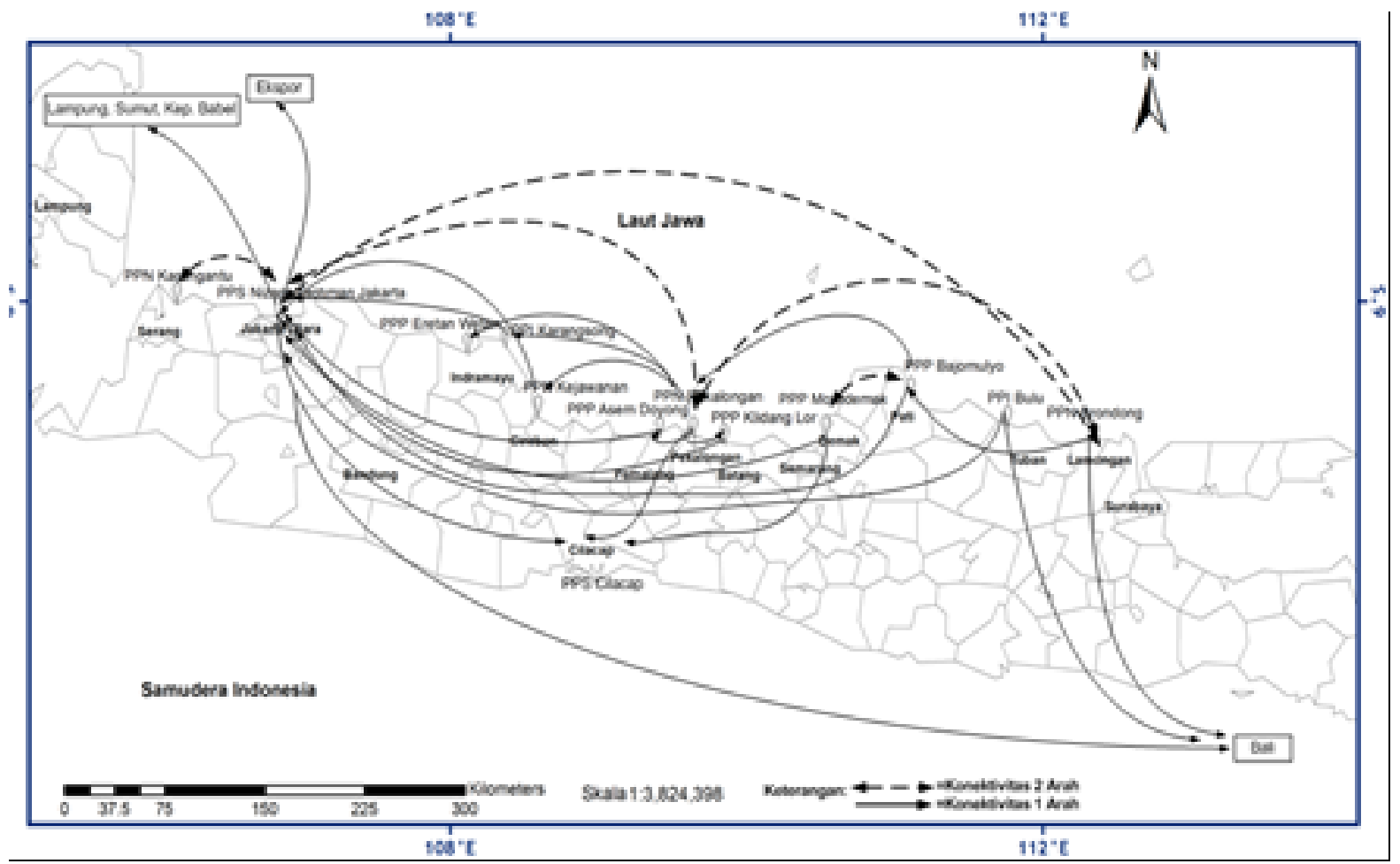

Gambar 2. Pola distribusi hasil tangkapan di Pantura Jawa berdasarkan konektivitas berdasarkan konektivitas 
Tabel 3. Konektivitas 12 pelabuhan perikanan dalam distribusi ikan di Pantura Jawa

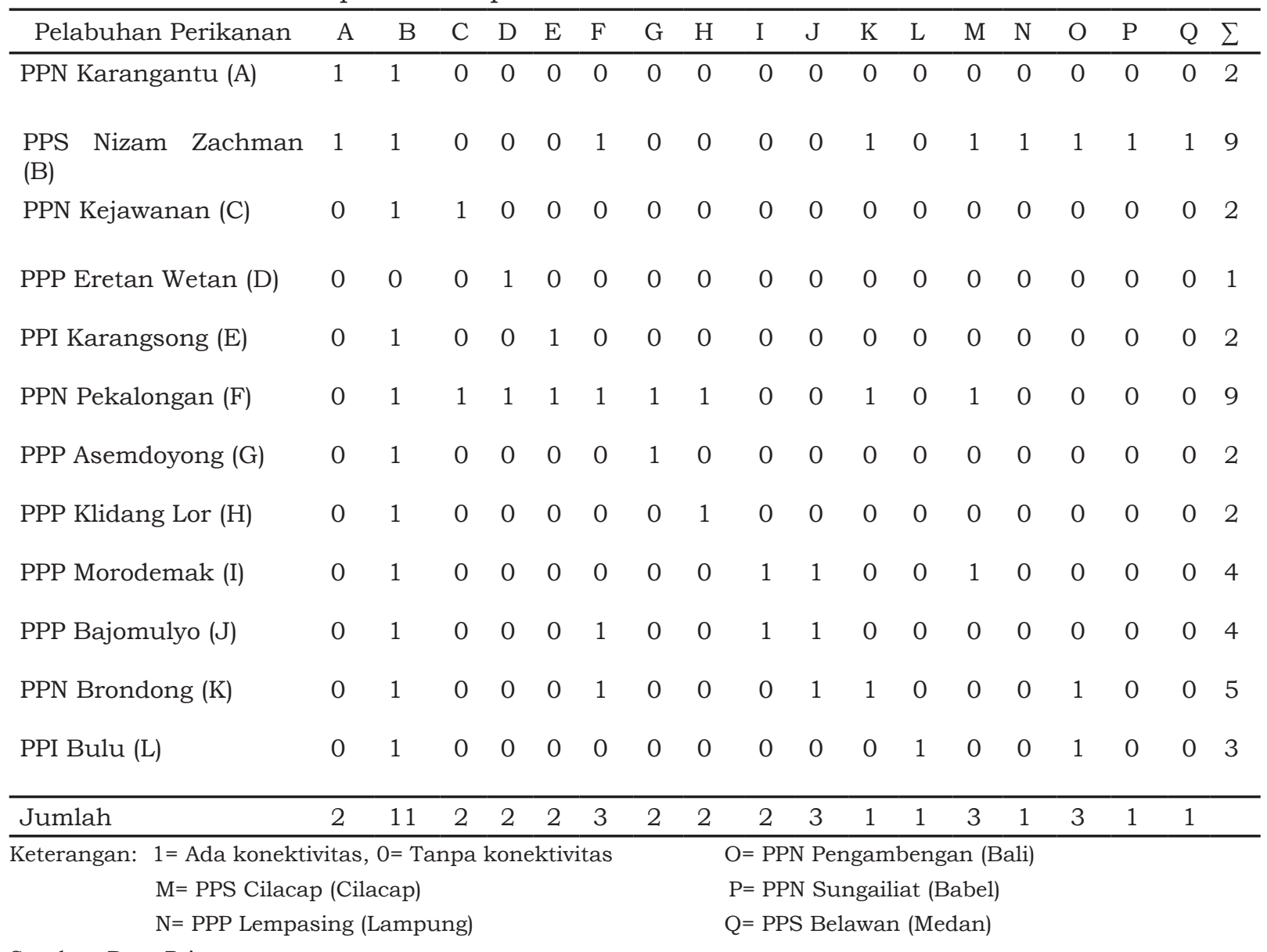

Sumber: Data Primer

\section{Distribusi hasil tangkapan berdasarkan pelaku pemasaran}

Distribusi hasil tangkapan pelabuhan perikanan di wilayah Pantura Jawa berdasarkan pelaku pemasaran didapatkan 7 pola yakni 5 pola berdasarkan produksi ikan dari dalam pelabuhan dan 2 pola berdasarkan produksi ikan dari luar pelabuhan. Pola pertama adalah pendistribusian dari nelayan ke Tempat Pelelangan Ikan (TPI) kemudian pedagang pengumpul/bakul dilanjutkan ke pedagang grosir, pengecer dan konsumen. Pola ini terjadi untuk memenuhi kebutuhan ikan segar penduduk setempat. Pola pertama terjadi pada PPN Pekalongan, PPP Eretan Wetan, PPI Karangsong, PPP Asemdoyong, PPP Klidang Lor, PPP Morodemak, PPP Bajomulyo. Pola kedua hampir sama dengan pola pertama, hanya saja pada pola ini ikan dari pedagang pengumpul setelah diolah maupun diawetkan kemudian dilanjutkan ke pedagang pengecer untuk kemudian dijual kepada konsumen. Umumnya pola ini terjadi untuk memenuhi kebutuhan ikan segar atau ikan olahan bagi penduduk di luar kota, meskipun tidak menutup kemungkinan produk ini dijual kepada penduduk setempat. Pola kedua seperti pada PPN Pekalongan, PPP Eretan Wetan, PPI Karangsong, PPP Asemdoyong, PPP Klidang Lor, PPP Morodemak, PPP Bajomulyo dan PPI Bulu.

Pola ketiga hampir sama dengan pola kedua, hanya saja pada pola ini ikan dari pedagang pengumpul diolah maupun diawetkan oleh industri pengolahan untuk selanjutnya diekspor. Pola ketiga seperti pada PPS Nizam Zachman. Terkait industri pengolahan, sumber bahan baku yang diperoleh oleh industri pengolahan di kawasan pelabuhan perikanan seperti PPS 
Nizam Zachman mayoritas berasal dari pelabuhan itu sendiri dan sebagian kecil pasokan dari luar pelabuhan. Hal tersebut sesuai pernyataan Lubis dan Sumiati (2011) bahwa perusahaan industri pengolahan ikan yang berlokasi di suatu pelabuhan perikanan atau sekitarnya umumnya menggunakan sebagian atau keseluruhan bahan bakunya dari pelabuhan perikanan tersebut.

Pola keempat adalah pendistribusian hasil tangkapan dari nelayan langsung ke pedagang pengecer dilanjutkan ke konsumen. Pola ini terjadi bila nelayan tidak melelang hasil tangkapan ikannya dan menjualnya langsung ke pedagang pengecer. Pola keempat terdapat pada PPN Karangantu, PPN Pekalongan, PPP Bajomulyo, PPN Brondong dan PPI Bulu.

Pola lima hampir sama dengan pola keempat hanya saja pada pola ini ikan dari nelayan kemudian diekspor melalui agen/ perusahaan perikanan. Pola kelima seperti pada PPS Nizam Zachman, PPN Kejawanan, PPN Brondong. Sedangkan pada pola keenam dan ketujuh ikan berasal dari luar pelabuhan melalui darat atau laut.

Pola keenam pendistribusian tanpa lelang dari pedagang grosir kemudian dilanjutkan ke pedagang pengecer, pasar tradisional, rumah makan dan lainnya sampai ke konsumen. Pola keenam seperti pada PPS Nizam Zachman dan PPN Brondong.

Pola ketujuh hampir sama dengan pola keenam, hanya hasil tangkapan ikan diolah oleh pedagang pengolah ikan tradisional kemudian selanjutnya ke pedagang pengecer, pasar, dan rumah makan hingga ke konsumen. Pola ketujuh seperti pada PPN Brondong. Bagan pola distribusi hasil tangkapan yang ada di 12 pelabuhan perikanan Pantura Jawa mulai dari ikan didaratkan hingga didistribusikan ke konsumen disajikan pada Gambar 3.
Panjang pendeknya pola distribusi yang berbeda dalam suatu hasil perikanan tergantung pada beberapa faktor. Hanafiah dan Saefuddin (2006) menyatakan bahwa faktor tersebut antara lain pertama, jarak antara produsen dan konsumen. Semakin jauh jarak antara produsen dan konsumen biasanya semakin panjang saluran yang ditempuh oleh produk. Kedua, cepat tidaknya produk rusak. Produk yang cepat rusak harus cepat diterima oleh konsumen, dengan demikian menghendaki saluran yang pendek dan cepat. Ketiga, skala produksi. Bila produksi berlangsung dalam ukuran kecil, maka jumlah produk yang dihasilkan berukuran kecil, dimana tidak akan menguntungkan bila produsen langsung menjualnya ke pasar. Dalam keadaan demikian kehadiran pedagang perantara diharapkan, sehingga saluran yang dilalui produk cenderung panjang. Keempat, posisi keuangan pengusaha. Produsen yang kuat modalnya cenderung untuk memperpendek saluran tata niaga.

Penelitian Johanson (2013) menyebutkan bahwa pemasaran yang efektif diindikasikan dengan pola saluran distribusi yang efisien antara lain relatif sedikitnya keterlibatan pedagang perantara dan jalur distribusi relatif pendek. Terkait harga, semakin panjangnya jalur distribusi pemasaran maka harga yang terbentuk semakin tinggi. Pada penelitian ini pola distribusi hasil tangkapan berdasarkan pelaku pemasaran di pantura Jawa masih belum efisien karena masih terdapat panjang dan banyaknya pedagang perantara dalam saluran distribusi yang terlibat. Jalur distribusi hasil tangkapan berupa ikan segar di pelabuhan Pantura Jawa termasuk kedalam saluran distribusi tidak langsung. Kedua belas pelabuhan ini mendistribusikan melalui beberapa perantara diantaranya produsen (nelayan)-pedagang pengumpul (bakul)-pedagang grosir-pedagang pengecerkonsumen. 


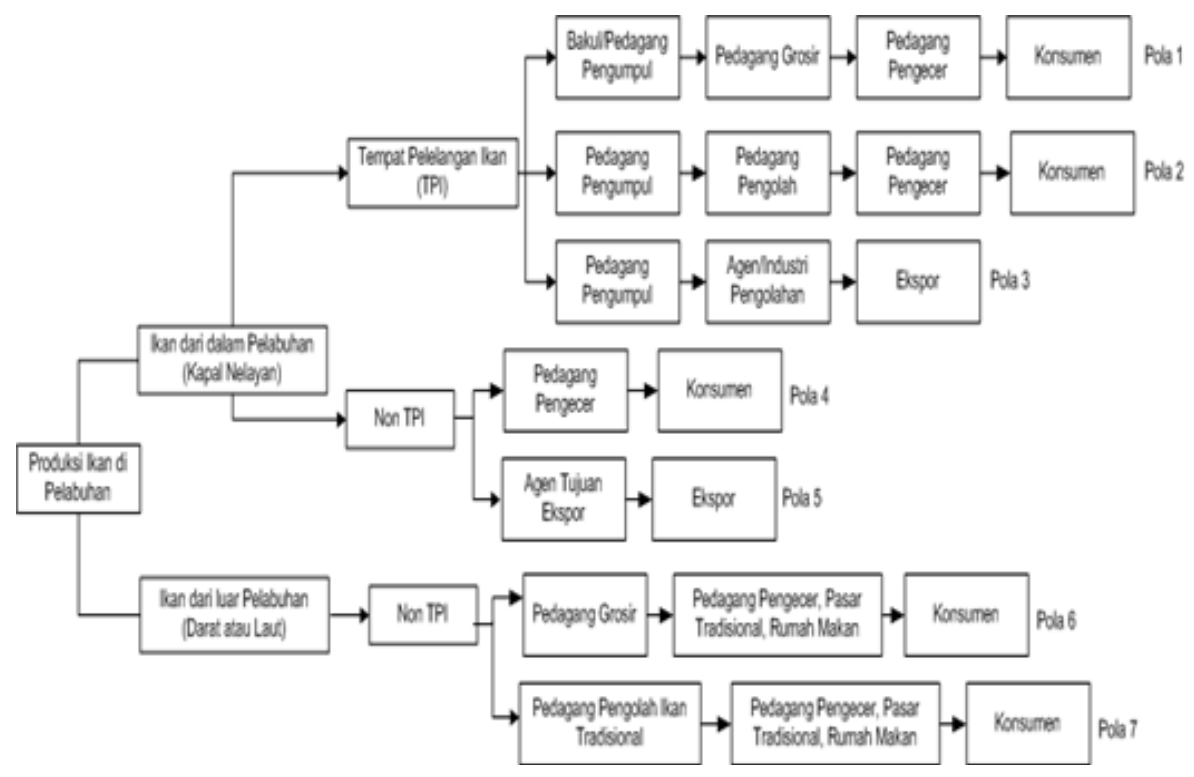

Gambar 3. Pola distribusi hasil tangkapan berdasarkan pelaku pemasaran

\section{KESIMPULAN DAN SARAN}

\section{Kesimpulan}

Pola distribusi hasil tangkapan pelabuhan perikanan di Pantura Jawa dikelompokkan menjadi 3 yaitu distribusi hasil tangkapan berdasarkan pasar, konektivitas dan pelaku pemasaran. Pola distribusi hasil tangkapan berdasarkan pasar dibagi menjadi 4 tipe yaitu distribusi pasar lokal, regional, luar Jawa dan luar negeri. Pola distribusi hasil tangkapan berdasarkan konektivitas pelabuhan perikanan didapatkan bahwa pelabuhan perikanan sebagai pemasar adalah PPS Nizam Zachman. Pola distribusi hasil tangkapan pelabuhan perikanan berdasarkan pelaku pemasaran didapatkan 7 pola yakni 5 pola berdasarkan produksi ikan dari dalam pelabuhan dan 2 pola berdasarkan produksi ikan dari luar pelabuhan.

\section{Saran}

Perlu adanya penelitian lanjutan yang menganalisis tentang aspek peningkatan pasar ekspor dengan peningkatan mutu hasil tangkapan di pelabuhan perikanan. Optimalisasi sistem teknologi informasi dan komunikasi antar pelabuhan yang terintegrasi guna menjamin kepastian tersedianya pasokan ikan secara berkelanjutan, peningkatan fasilitas sarana transportasi yang efisien berkaitan dengan pendistribusian hasil tangkapan dan penguatan bargaining position nelayan dalam pemasaran ikan.

\section{DAFTAR PUSTAKA}

Charles AT. 2001. Sustainable Fishery Sistems. United Kingdom (GB): Blackwell Science.

Clucas IJ, Ward AR. 1996. Post Harvest Fisheries Development : A Guide Handling, Preservation, Processing and Quality. United Kingdom (GB). Natural Resources Institute. $428 \mathrm{pp}$.

Hanafiah AM, Saefuddin AM. 2006. Tata Niaga hasil perikanan. Jakarta (ID): UI Pr.

Johanson D. 2013. Analisis efisiensi pola distribusi hasil penangkapan ikan nelayan kecamatan kahayan kuala kabupaten pulang pisau. Jurnal Sains Manajemen. 1(1):96-109.

[KKP] Kementerian Kelautan dan Perikanan. 2014. Analisis Data Pokok Kelautan dan Perikanan 2014. Jakarta (ID): Pusdatin KKP.

[KKP] Kementerian Kelautan dan Perikanan. 2015. Pusat Informasi Pelabuhan Perikanan. Jakarta (ID): Direktorat Pelabuhan Perikanan.

Lubis E dan Sumiati. 2011. Pengembangan industri pengolahan ikan ditinjau dari produksi hasil tangkapan di PPN Palabuhanratu. Jurnal Marine Fisheries. 2(1):40-47.

Lubis E. 2011. Kajian peran strategis pelabuhan perikanan terhadap pengembangan perikanan laut. Akuatik Jurnal Sumberdaya Perairan. 5(2):1-7. 
Mai N, BogasonS, Arason S, Árnason S, Matthiasson T. 2010. Benefits of traceability in fish supply chainscase studies. British Food Journal. 112:976-1002.

Muninggar R. 2008. Analisis supply chain dalam aktivitas distribusi di PPN Palabuhanratu. Jurnal Buletin PSP. 17(3):350-355

Nazir M. 2011. Metodologi penelitian. Bogor : Ghalia Indonesia.

[PKSPL-IPB] Pusat Kajian Sumberdaya Pesisir dan Lautan. 2000. Studi Pengembangan Pelabuhan Perikanan di Pantura Jawa Serta Sistem Data dan Informasi. Bogor: PKSPL-IPB.
Slamet G. 2013. Analisis saluran distribusi dan perilaku konsumen. Jurnal Mimbar Bumi Bengawan. 6(13):40-47.

Srinivasan UT. 2010. Food security implications of global marine catch losses due to overfishing. Journal of Bioeconomics. 12(3):183-200.

Solihin I, Putri TE. 2012. Pola interaksi antar pelabuhan perikanan di kabupaten sukabumi. Jurnal Buletin PSP. 20(3):347-358. 